\title{
SCientific Articlew
}

\section{Efficiency of Spathiphyllum spp. as a plant-microbial fuel cell}

\author{
Kei Jung Kwon ${ }^{1}$ (i) and Bong Ju Park ${ }^{1}$ (1) \\ ${ }^{1}$ Chungbuk National University, Cheongju, Republic of Korea.
}

\begin{abstract}
The purpose of this study was to investigate the utility of an ornamental plant, Spathiphyllum spp., as a plant-microbial fuel cell (Plant MFC) to produce voltage and current. This study also evaluated the effect of the Plant MFC on water use efficiency and plant growth. The experiment used four experimental groups: used MFC without plant (Soil MFC), used MFC with plant (Plant MFC), unused MFC without plant (Soil Pot), and unused MFC with plant (Plant Pot). Plant MFC generated higher voltage and current levels than Soil MFC. The average voltage of Plant MFC and Soil MFC was $0.475 \mathrm{~V}$ and $0.375 \mathrm{~V}$, respectively, and the average current was $0.110 \mathrm{~mA}$ and $0.030 \mathrm{~mA}$, respectively. Plant MFC using Spathiphyllum spp. produced a constant voltage output, with a deviation of $0.027 \mathrm{~V}$ during the four-month indoor experiment. The difference between the maximum and minimum voltage during the day was as small as $0.015 \mathrm{~V}$, which supports the utility of Plant MFC as a stable power source. Volumetric soil moisture content, chlorophyll fluorescence (Fv/Fm), photosynthesis rate, leaf area, fresh weight, and dry weight of Plant MFC and Plant Pot were measured. There was no significant difference in any values, and volumetric soil moisture and plant growth were not affected by the utilization of Plant MFC. Thus, a Plant-MFC using Spathiphyllum spp. can play the same ornamental role as conventional plants and at the same time be used as a sustainable bioelectricity source.
\end{abstract}

Keywords: bioelectricity, energy harvesting, photosynthetic MFC, renewable energy, sustainable energy.

\section{Resumo}

Eficiência de Spathiphyllum spp. como célula de combustível microbiana de planta

O objetivo deste estudo foi investigar a utilidade de uma planta ornamental, Spathiphyllum spp., como célula de combustível microbiana de planta (CCM de Planta) para produzir tensão e corrente. Este estudo avaliou também o efeito da CCM de Planta na eficiência do uso da água e no crescimento da planta. A experiência utilizou quatro grupos experimentais: CCM usada sem planta (CCM de Solo), CCM usada com planta (CCM de Planta), CCM não usada sem planta (Vaso com Solo) e CCM não usada com planta (Vaso com Planta). A CCM de Planta gerou níveis de tensão e corrente mais elevados do que a CCM de Solo. A tensão média da CCM de Planta e da CCM de Solo foi de $0,475 \mathrm{~V}$ e 0,375 V, respetivamente, e a corrente média foi de $0,110 \mathrm{~mA}$ e $0,030 \mathrm{~mA}$, respetivamente. A CCM de Planta usando Spathiphyllum spp. produziu uma saída de tensão constante, com um desvio de $0,027 \mathrm{~V}$ durante a experiência de quatro meses em ambiente protegido. A diferença entre a tensão máxima e mínima durante o dia era tão pequena quanto $0,015 \mathrm{~V}$, o que apoia a utilidade da CCM de Planta como uma fonte de energia estável. Foram medidos o teor de humidade volumétrico do solo, fluorescência da clorofila (Fv/Fm), taxa de fotossíntese, área foliar, peso fresco e peso seco da CCM de Planta e do Vaso com Planta. Não houve diferença significativa em nenhum dos valores, e a humidade volumétrica do solo e o crescimento da planta não foram afetados pela utilização da CCM de Planta Assim, uma CCM de Planta usando Spathiphyllum spp. pode desempenhar o mesmo papel ornamental das plantas convencionais e ao mesmo tempo ser utilizada como uma fonte de bioeletricidade sustentável.

Palavras-chave: bioeletricidade, captação de energia, CCM fotossintética, energia renovável, energia sustentável.

\section{Introduction}

The world's population is steadily increasing. Consequently, consumption of fossil fuels is also increasing, leading to worldwide concerns about fossil fuel shortages.
Alternative energy sources are needed due to environmental problems associated with the use of fossil fuels, including $\mathrm{CO}_{2}$ emission, global warming, and pollution. Solar cells and wind power are alternative energy sources with unlimited supply (Erickson and Jennings, 2017; Zhang

*Corresponding author: bjpak@chungbuk.ac.kr 
et al., 2017; Guo et al., 2018). In addition, research into various biotechnologies that will provide alternative energy sources and reduce greenhouse gas emissions is ongoing. One such technology involves the use of microbial fuel cells (MFCs) as a sustainable and environmentally friendly power source (Tommasi and Lombardelli, 2017; Hung et al., 2019; Elshobary et al., 2020). In an MFC, microbial catalysts oxidize organic matter to generate water and electricity through the flow of electrons and hydrogen ions between the anode and cathode (Abourached et al., 2016; $\mathrm{Xu}$ et al., 2016; Shuba and Kifle, 2018).

A Plant-MFC is powered by plant photosynthesis. The organic matter that is produced by photosynthesis moves from leaves to roots. Roots exude organic matter into the soil. Microorganisms living in the soil continuously decompose the exuded organic matter. Finally, electrical energy is generated through such processes (Nitisoravut and Regmi, 2017; Sathish-Kumar et al., 2017; Chicas et al., 2018; Kabutey et al., 2019).

$\mathrm{Fu}$ et al. (2009) investigated the impact of biomass and light intensity on Plant-MFC performance by using the microalgae Spirulina platensis to generate electricity day and night. They also examined the relationship of open circuit voltage and light intensity with optimal biomass area density. Fu et al. (2010) also assessed the possibility of using a Plant-MFC as an ordinary battery, which is ready-to-use and portable, by investigating the electrical response of the microalgae Spirulina platensis. Voltage was immediately generated as soon as Spirulina platensis attached to the anode $(+)$. As is the case with batteries, Plant-MFCs produced a high voltage when connected in series. Plant-MFCs also generated a high current when connected in parallel. Helder et al. (2013) found that most electricity is produced at the top of the system, with less internal resistance and the largest number of roots. Im et al. (2014) studied the size of electrodes and reported that the amount of electric power produced decreases when the internal resistance is increased by a long distance between electrodes or small electrode size. Sophia and Sreeja (2017) found that addition of three species (Brassica juncea, Trigonella foenumgraecum, and Canna Stuttgart) to compost is related to the production of bio-energy. Those authors showed that both plant species and compost added to soil are closely related to the amount of electric power that is produced. In addition to plant species, a few other factors can also influence power generation by Plant-MFC, including the distance between plant roots and electrodes, the material used for the electrodes, and the precise composition of the Plant-MFC (Ahn et al., 2014). Deng et al. (2012) also reported on power production by a PlantMFC, and looked at configurations, plant types, anode and cathode materials, bacterial communities, possible applications, and future directions for the technology. And they suggested that green energy can be used in many areas. Lin et al. (2015) tested a self-powered and wireless environmental monitoring system that uses soil energy. Sudirjo et al. (2019) created a Plant-MFC application for the maintenance of rice paddy fields and the growth and production of rice crop. Brunelli et al. (2016) and Rosa et al. (2019) reported the possibility of wireless and batteryless monitoring of plant health status and environmental data using a Plant-MFC. This system is renewable and costeffective; an atmospheric humidity sensor, microcontroller, and low-energy Bluetooth transmitter are connected to the Plant-MFC, and there is no need to change any batteries. The monitoring system can generate energy through a reaction between soil moisture and microorganisms. Ecofriendly energy sources such as solar power, wind power, and MFCs can generally be applied in specific areas, such as monitoring in different field environments, because they supply power to remote sensors without necessitating regular battery changes, although their energy conversion efficiencies are low (Lin et al., 2015; Alsharif et al., 2018; $\mathrm{Xu}$ et al., 2019). Therefore, continued research on such eco-friendly energy sources is required.

The decline in green space associated with urbanization is increasing the demand for ornamental plants, leading to increased rooftop greening, wall greening and indoor gardening. Previous studies have focused on the energy efficiency of Plant-MFCs. However, research on the effects of Plant-MFCs on plant growth is lacking.

This study investigated the possibility of using an ornamental plant, Spathiphyllum spp., as a Plant-MFC. The voltage and current production of the Plant-MFC and the effects of Plant-MFC on the water use efficiency and growth of the plant were evaluated.

\section{Materials and Methods}

Spathiphyllum patinii was used as plant material in this study. Spathiphyllum spp. is a houseplant of Araceae family. Spathiphyllum spp. has been used in various studies for purifying indoor air by removing gaseous pollutants, such as volatile organic compounds, and particulate pollutants, such as $\mathrm{PM}_{10}$ and $\mathrm{PM}_{2.5}$. It has also been studied for improving indoor temperature and humidity (Hörmann et al., 2018; Kwon and Park, 2018; Parseh et al., 2018).

Individual Spathiphyllum spp. plants, all with the same plant height, number of leaves, and a fresh weight of 50 $\mathrm{g}$, were selected for this study. They were then planted in perlite (Paraso, Kyungdong One, South Korea) on a plastic pot with a diameter of $10 \mathrm{~cm}$ to minimize the effects of soil organic matter. Chemical of perlite was tested by the Rural Development Administration method (Lee et al., 2006) (Table 1). We did not add fertilizer, and we only watered the plants during the experiment. 
Table 1. Chemical properties of perlite used in this study

\begin{tabular}{|c|c|c|c|c|c|c|c|c|}
\hline pH & EC & OM & $\mathbf{T}-\mathbf{N}$ & $\mathrm{Av}-\mathrm{P}_{2} \mathrm{O}_{5}$ & CEC & Ex-K & Ex-Ca & Ex-Mg \\
\hline & $\left(\mathrm{dS} \mathrm{m}^{-1}\right)$ & $(\%)$ & (\%) & $\left(\mathrm{mg} \mathrm{kg}^{-1}\right)$ & \multicolumn{4}{|c|}{$\left(\mathrm{Cmol}^{+} \mathrm{kg}^{-1}\right)$} \\
\hline 5.80 & 0.01 & 0.98 & 0.01 & 15.3 & 0.78 & 0.04 & 0.02 & - \\
\hline
\end{tabular}

A fluorescent lamp was used as a light source. The experiment was performed after photoadaptation with an intensity of about $40 \mu \mathrm{mol} \cdot \mathrm{m}^{-2} \cdot \mathrm{s}^{-1}$ PPFD and establishment of a light cycle of 12/12 h (day/night). We used a sub-irrigation system to maintain a constant soil moisture level. The soil moisture content was measured using an FDR sensor (ML2x, Delta-T Devices, UK). A single chamber was used for the Plant-MFC. A plate-shaped electrode with a width of $1 \mathrm{~cm}$ and a length of $2.5 \mathrm{~cm}$ was used. Copper $(\mathrm{Cu})$ was used for the positive electrode $(+)$, zinc $(\mathrm{Zn})$ was used for the negative electrode (-), and the electrode spacing was fixed at $1 \mathrm{~cm}$. Silicon coupling rings were used for each pot to maintain constant depth and distance. To assess the maximum output, the Plant-MFC voltage was measured in an open circuit not connected to any resistance. The current was measured in a short-circuited condition to obtain the maximum current. Open circuit voltage and short circuit current were continuously measured during the experimental period using data loggers such as Onset HOBO model UX120-006M and Onset Computer Corporation-USA (Figure 1).
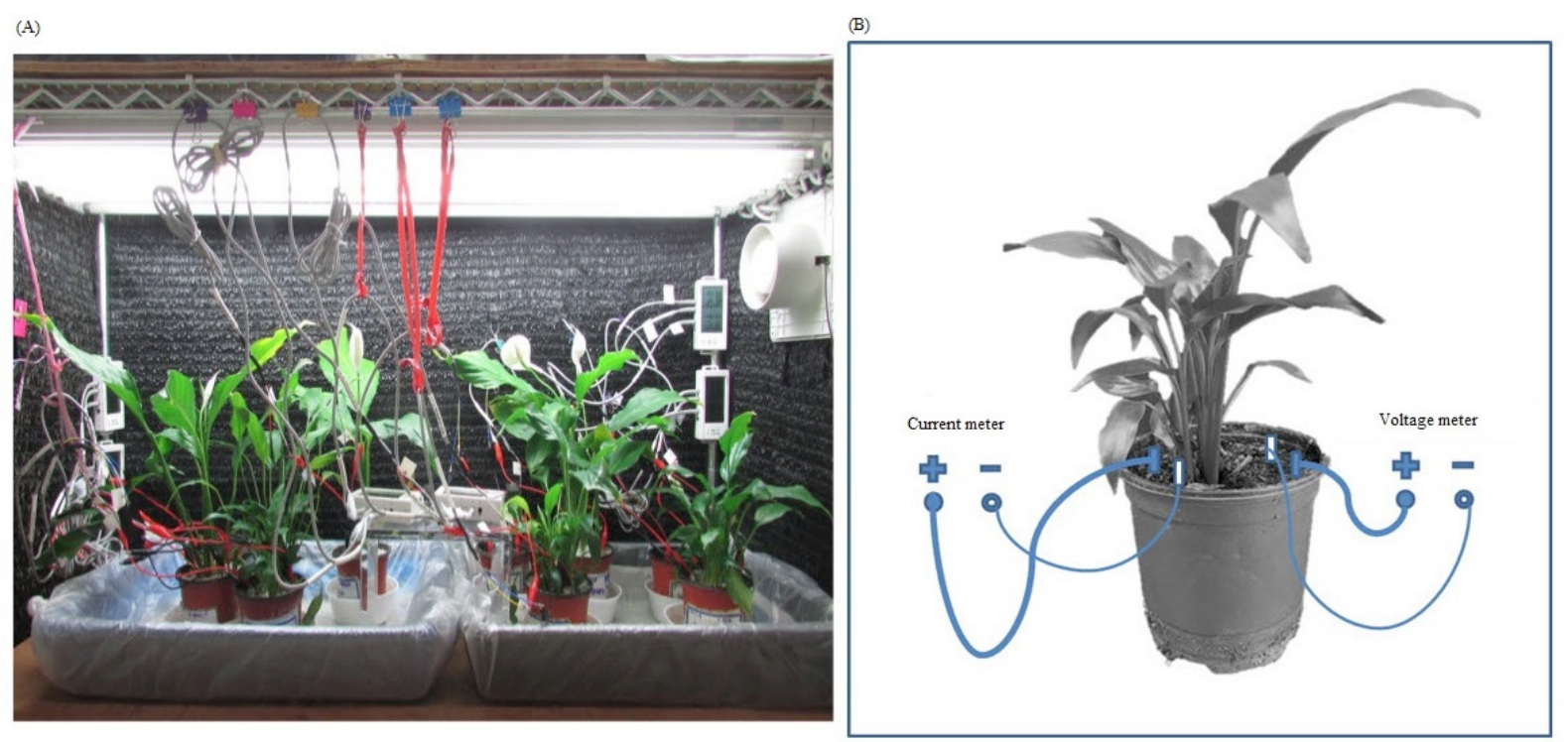

Figure 1. Experimental setup. (A) Photograph of the Plant-MFC, (B) Voltage and current measurements of the Plant-MFC.

The present experiment examined four different groups: 1) Soil-MFC, which was only soil without plants, 2) Plant-MFC, which had plants, 3) Soil Pot, which had neither plants nor an MFC, and 4) Plant Pot, which had plants that were not used as an MFC. We compared voltage and current generation between Soil-MFC and Plant-MFC to test whether the presence of the plant was associated with changes in voltage and current production. Additionally, to determine the effect of Plant-MFC installation on plant growth, we examined chlorophyll fluorescence $(\mathrm{Fv} /$ Fm), photosynthetic rate, leaf area, fresh weight, and dry weight of both the aboveground and underground portions of the plant. We measured Fv/Fm and photosynthetic rate every two weeks. Fv/Fm was assessed with a chlorophyll fluorescence analyzer (PAM2000, Walz, Germany) after treatment with a darkness adaptive clip for 30 minutes. Photosynthetic rate was measured between 10:00 AM and 1:00 PM using a photosynthetic analyzer (Li-6400, Li-COR Inc., USA) under the following leaf chamber conditions: light intensity of $40 \mu \mathrm{mol} \cdot \mathrm{m}^{-2} \cdot \mathrm{s}^{-1} \mathrm{PPFD}$, air flow rate of $250 \mu \mathrm{mol} \cdot \mathrm{s}^{-1}$, temperature of $25{ }^{\circ} \mathrm{C}$, and carbon dioxide concentration of $400 \mu \mathrm{mol} \mathrm{CO}_{2} \cdot \mathrm{mol}^{-1}$. We measured leaf area and both fresh and dry weight of plant shoots and roots at the end of the experiment. 
Dry weight was measured after the plant was dried for 70 hours in a hot air-circulating dryer at $70{ }^{\circ} \mathrm{C}$ (HB$502 \mathrm{M}$, Hanbaek Science, South Korea). Leaf area size was measured using a leaf area meter (Li-3000A, LiCOR Inc., USA). The experiment was performed in an indoor laboratory over the course of four months, from May to September 2016.

An experiment was repeated three times within each group. We used the SAS 9.3 program (SAS Institute Inc., USA) for all statistical analyses. Statistical significance was considered at $\mathrm{p}<0.05$, which was taken to indicate meaningful differences between treatment averages using Duncan's multiple range test (DMRT).

\section{Results and Discussion}

\section{Comparison of Plant-MFC and Soil-MFC in Terms} of Voltage and Current

Plant-MFC produced higher voltage and current than did Soil-MFC (Figure 2). An average Plant-MFC voltage and current were 1.27 times and 3.7 times higher than that of Soil-MFC, respectively.

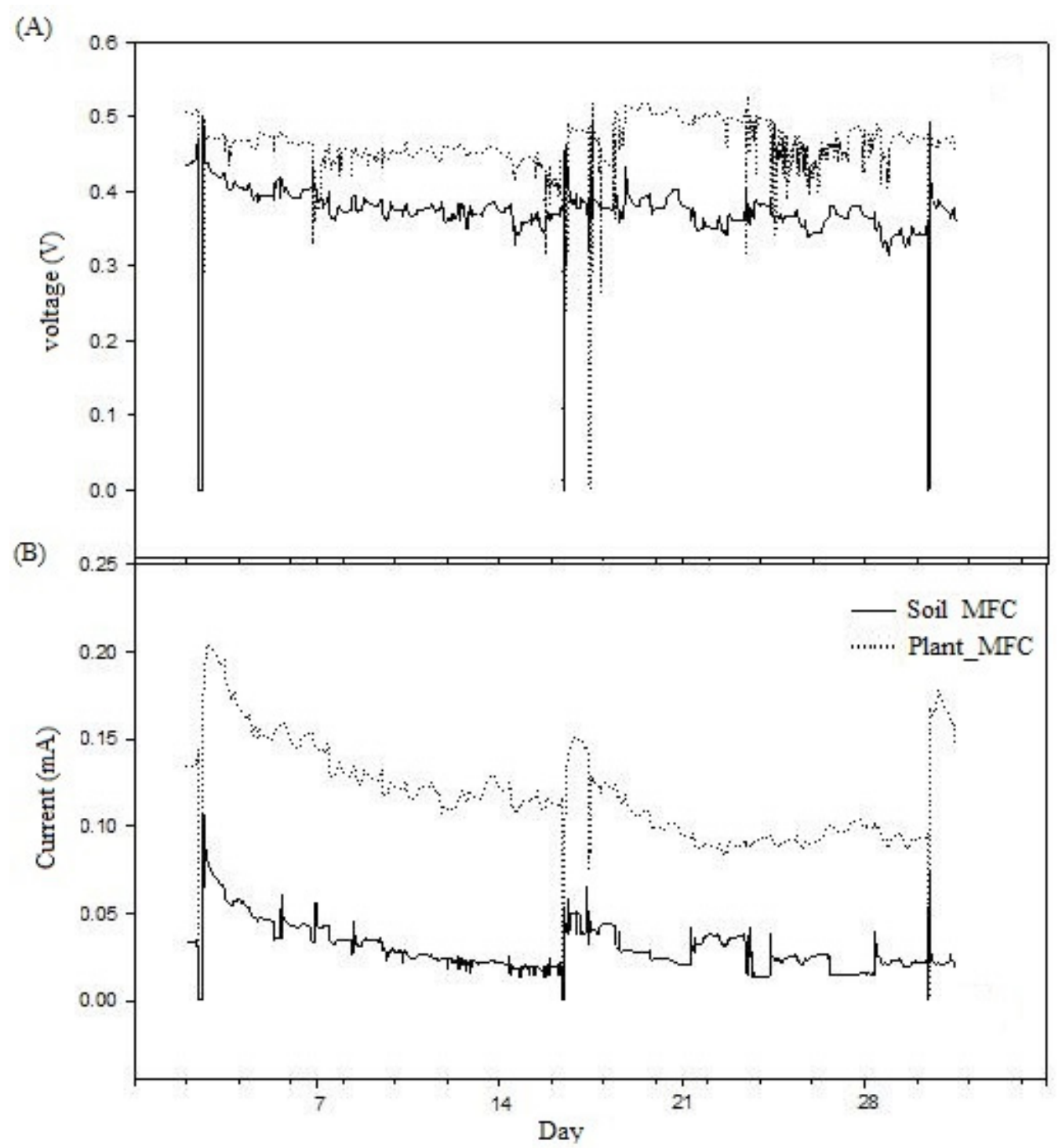

Figure 2. Comparison of voltage. (A) and current (B) generation between Soil-MFC and Plant-MFC $(\mathrm{n}=3)$. The severe fluctuations in the center of the graph reflect the process of disconnecting and reconnecting the MFC for physiological measurement purposes. 
Such findings are consistent with the results of Ahn et al. (2014) and Regmi et al. (2018), who showed that the voltage and current of Plant-MFC were higher than those of Soil-MFC (unplant-MFC) in their experiment using Oryza sativa and vetiver plants as a Plant-MFC. Certain root by-products that emerged in the process of photosynthesis might have affected MFC voltage and current generation. In a Plant-MFC experiment using Oryza sativa in the field, there was almost no difference in the voltage of the MFC according to the presence of plants for one month after transplantation of Oryza sativa. However, there was a difference in voltage since August, during the period in which Oryza sativa showed rapid growth. This difference depended on the presence of plants (Ahn et al., 2014). The degree of voltage fluctuation was substantial during the experimental period of four months, beginning in August.

Spathiphyllum spp. grew for four months in an indoor setting. However, it did not grow as much as Oryza sativa. The voltages of Plant-MFC and Soil-MFC were
$0.465 \pm 0.027 \mathrm{~V}$ and $0.373 \pm 0.018 \mathrm{~V}$, respectively, during the experimental period, indicating relatively constant voltage generation. The only exception was during the two days in which the Plant-MFC was separated from the data logger in order to measure growth and soil moisture. PlantMFC was reconnected to stabilize the voltage.

The average voltages of Plant-MFC and Soil-MFC over the course of ten days (July 4-8 and July 16-20, when voltage and current were relatively constant) were $0.475 \pm$ $0.030 \mathrm{~V}$ and $0.375 \pm 0.013 \mathrm{~V}$, respectively. According to the study on enhanced bio-electricity generation in a plant microbial fuel cell with electrochemically modified carbon fiber brush anode, it was reported that Dracaena braunii and Epipremnum aureum generated the respective peak voltage of $0.432 \mathrm{~V}$ and $0.620 \mathrm{~V}$ within a similar voltage range (Sarma and Mohanty, 2018).

The average currents for the same period were 0.110 $\pm 0.018 \mathrm{~mA}$ and $0.030 \pm 0.006 \mathrm{~mA}$, respectively (Table 2).

Slightly different voltage and current values were seen at different time points in a single day (Figure 3).

Table 2. Average voltage and current according to MFC type $(n=10)$.

\begin{tabular}{|c|c|c|}
\hline Plot & Voltage $(\mathrm{V})$ & Current $(\mathrm{mA})$ \\
\hline Soil-MFC & $0.375 \pm 0.013 \mathrm{~b}^{\mathrm{z}}$ & $0.030 \pm 0.006 \mathrm{~b}$ \\
\hline Plant-MFC & $0.475 \pm 0.030 \mathrm{a}$ & $0.110 \pm 0.018 \mathrm{a}$ \\
\hline Significance & $* * *$ & $* * *$ \\
\hline
\end{tabular}

\footnotetext{
${ }^{\mathrm{z}}$ Means separation with columns according to Duncan`s multiple range test, $p=0.05$

ns = non-significant;

${ }^{* * * * * * * *}=$ significant at $p=0.05,0.01$, and 0.001 , respectively.
}

This may be related to the fact that the light was on between 8:00 AM and 8:00 PM during the experiment and the central air conditioner was operated between 12:00 PM and 05:00 PM. The 10-day average voltage gradually increased starting from 8:00 AM, when the light was turned on. However, it decreased after 12:00 PM, when the air conditioner was switched on. The voltage increased again after 5:00 PM, when the air conditioner was turned off. It then gradually decreased after 8:00 PM, when the light was turned off (Figure 3A). Current fluctuation displayed a similar pattern as voltage (Figure 3B). Bombelli et al. (2013) and Regmi et al. (2018) reported that the fluctuation of voltage by time within a day is caused by the effect of root exudates produced by photosynthesis. The present study indicates that the voltage fluctuation of Plant-MFC by time may be more strongly related to temperature change due to the operation of a fluorescent lamp and an air conditioning unit than the effect of root exudates, as suggested by Ahn et al. (2014). Plant-MFC and Soil-MFC showed similar trends in voltage fluctuation over time. In the rooftop experiment conducted by Helder et al. (2013), Plant-MFC was influenced by temperature. Voltage production decreased at low temperature. Plant-MFC using Oryza sativa showed considerable variation in day and night voltage due to diurnal variation in temperature (Ahn et al., 2014). The voltage gap between day and night was about $0.05 \mathrm{~V}$ in experiments using Phalaris arundinacea and Glyceria maxima (Blossfeld et al., 2011). The current experiment, which maintained a constant indoor temperature of 25 ${ }^{\circ} \mathrm{C}$, revealed that the difference between the highest and the lowest daily voltages was only $0.015 \mathrm{~V}$, indicating that the variation in voltage of an indoor Plant-MFC is smaller than that of an outdoor Plant-MFC. This finding implies that light intensity and temperature can affect the activities of microorganisms and photosynthetic activities of plants, thus influencing the volume of electricity produced. 


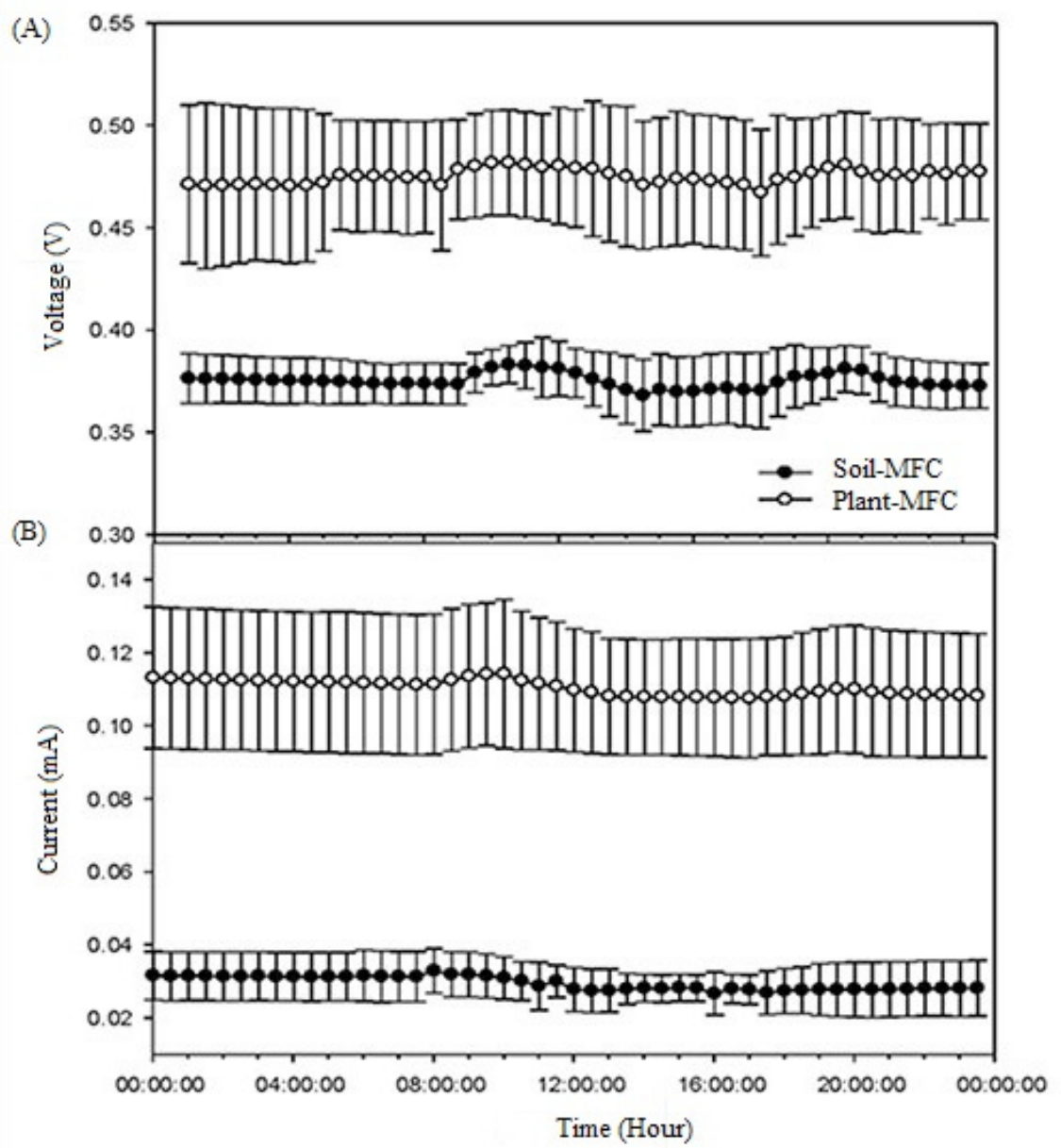

Figure 3. Daily fluctuation in voltage. (A) and current (B) between Soil-MFC and Plant-MFC. Values are means $\pm \operatorname{SE}(\mathrm{n}=10)$.

Effect of Plant-MFC on the water use efficiency and growth of plants

Previous research mostly used wastewater for MFC experiments, and focused on Plant-MFCs using Oryza sativa or other wetland plants. This may be related to the fact that water is important for microorganisms to ionize organic matter and transfer electrons and hydrogen ions to the electrodes. The levels of soil moisture of the Soil pot and the Soil-MFC were almost the same. Soil moisture of the Soil pot was between 58.17 and $71.60 \%$, and that of the Soil-MFC was between 57.70 and $65.70 \%$ when we watered them the same amount. Likewise, soil moisture of
Plant pot was between 34.23 and $46.40 \%$, and that of PlantMFC was between $34.67 \%$ and $42.53 \%$. In other words, the levels of soil moisture between Plant pot and PlantMFC were also almost the same. Therefore, no significant difference in the level of soil moisture was found according to the use of MFC. However, soil moisture of Plant pot and Plant MFC was in the range of between 34.67 and $46.40 \%$, and the soil moisture of Soil pot and Soil MFC was between 57.70 and $71.60 \%$, indicating a significant difference in the level of soil moisture according to the presence of plants. This finding may be due to evapotranspiration of the plant (Table 3). 
Table 3. Volumetric soil moisture content $(\%, \mathrm{n}=3)$.

\begin{tabular}{|c|c|c|c|c|}
\hline Plot & $\mathbf{1}$ day & $\mathbf{1 5}$ days & $\mathbf{3 0}$ days & $\mathbf{4 5}$ days \\
\hline Soil Pot & $58.17 \mathrm{a}^{\mathrm{z}}$ & $71.60 \mathrm{a}$ & $68.67 \mathrm{a}$ & $68.37 \mathrm{a}$ \\
\hline Plant Pot & $37.80 \mathrm{~b}$ & $46.40 \mathrm{c}$ & $39.97 \mathrm{c}$ & $34.23 \mathrm{~b}$ \\
\hline Soil-MFC & $57.70 \mathrm{a}$ & $65.70 \mathrm{~b}$ & $64.17 \mathrm{~b}$ & $63.80 \mathrm{a}$ \\
\hline Plant-MFC & $34.67 \mathrm{~b}$ & $40.03 \mathrm{~d}$ & $41.53 \mathrm{c}$ & $35.80 \mathrm{~b}$ \\
\hline Significance & $* * *$ & $* * *$ & $* * *$ & $* * *$ \\
\hline
\end{tabular}

${ }^{\mathrm{z}}$ Means separation with columns according to Duncan`s multiple range test, $p=0.05$.

ns = non-significant;

$*, * *, * * * *$ Significant at $p=0.05,0.01$, and 0.001 , respectively.

There was no significant difference in soil moisture content between Plant-MFC and Plant Pot on June 29 or August 11. However, a significant difference appeared on July 13 and July 28. This may be due to the difference in plant growth caused by flowering of each plant. Paredes and Quiles (2017) reported that Spathiphyllum lanceifolium showed an Fv/Fm value of $0.7-0.8$ at a shade light intensity of $800 \mu \mathrm{mol} \cdot \mathrm{m}^{-2} \cdot \mathrm{s}^{-1}$ PPFD. Kwon and Park(2018) used Spathiphyllum spp. in their study for particulate matter removal of an indoor plant according to light intensity to measure photosynthetic rates, and reported a photosyntheic rate of 4.4 at $60 \mu \mathrm{mol} \cdot \mathrm{m}^{-2} \cdot \mathrm{s}^{-1}$ PPFD. In this study, it was found that those plants with the above range of FV/FM values and photosynthetic rates at 40 $\mu \mathrm{mol} \cdot \mathrm{m}^{-2} \cdot \mathrm{s}^{-1}$ PPFD showed normal growth. No significant difference was found in $\mathrm{Fv} / \mathrm{Fm}$ or photosynthetic rate (which were taken as measures of plant stress caused by being used as a Plant-MFC) between Plant-MFC and Plant Pot (Table 4).

Leaf area, fresh weight, and dry weight values after the end of the experiment did not significantly differ between Plant-MFC and Plant Pot (Table 5).

Table 4. Change of Fv/Fm and photosynthetic rate in Plant Pot and Plant-MFC $(n=3)$.

\begin{tabular}{|c|c|c|c|c|}
\hline \multirow{2}{*}{ Plot } & \multicolumn{2}{|c|}{ Fv/Fm } & \multicolumn{2}{c|}{$\begin{array}{c}\text { Photosynthetic rate } \\
\left(\boldsymbol{\mu m o l C O} \cdot \mathbf{m}^{-2} \cdot \mathbf{s}^{-\mathbf{1}}\right)\end{array}$} \\
\hline Plant Pot & 1day & 30days & 1day & 30days \\
\hline Plant-MFC & $0.683 \mathrm{a}^{\mathrm{z}}$ & $0.762 \mathrm{ab}$ & $2.58 \mathrm{a}$ & $3.21 \mathrm{a}$ \\
\hline Significance & $0.706 \mathrm{a}$ & $0.733 \mathrm{~b}$ & $1.81 \mathrm{a}$ & $3.36 \mathrm{a}$ \\
\hline & $\mathrm{ns}$ & $\mathrm{ns}$ & $\mathrm{ns}$ & $\mathrm{ns}$ \\
\hline
\end{tabular}

\footnotetext{
${ }^{\mathrm{z}}$ Means separation with columns according to Duncan`s multiple range test, $\mathrm{p}=0.05$. ns $=$ non-significant;

***,**** Significant at $\mathrm{p}=0.05,0.01$, and 0.001 , respectively.
}

Table 5. Comparison of leaf area, fresh weight, and dry weight between Plant Pot and Plant-MFC $(n=3)$.

\begin{tabular}{|c|c|c|c|}
\hline Plot & $\begin{array}{c}\text { Leaf area } \\
\left(\mathrm{cm}^{2} / \text { shoot }\right)\end{array}$ & $\begin{array}{c}\text { Fresh weight } \\
\text { ( g/shoot) }\end{array}$ & Dry weight ( g/shoot ) \\
\hline Plant Pot & $436.1 \mathrm{a}^{\mathrm{z}}$ & $40.53 \mathrm{a}$ & $7.60 \mathrm{a}$ \\
\hline Plant-MFC & $424.4 \mathrm{a}$ & $48.17 \mathrm{a}$ & $10.17 \mathrm{a}$ \\
\hline Significance & ns & ns & ns \\
\hline
\end{tabular}

\footnotetext{
${ }^{2}$ Means separation with columns according to Duncan`s multiple range test, $p=0.05$. 
Therefore, no significant change in soil moisture content or plant growth was observed, even if the plant was used as a Plant-MFC. To increase Plant-MFC efficiency, further studies are needed to examine the relationship between the aboveground and underground portions, selection of appropriate plant species, soil type, and light intensity.

\section{Conclusions}

Compared to the outdoor environment, the characteristics of the indoor environment, such as light, temperature, and humidity, remain relatively constant, so the growth of Spathiphyllum spp. for indoor landscaping progresses slowly, and when it is used as a Plant-MFC, there are slight fluctuations in daily and monthly voltage and current. In addition, when comparing plants used as Plant-MFCs and general potted plants, we found no significant differences in water use efficiency and growth. Thus, a Plant-MFC using Spathiphyllum spp. can play the same ornamental role as conventional plants and at the same time be used as a sustainable bioelectricity source.

\section{Author Contribution}

KJK: data analysis and manuscript preparation; BJP: design of this experiment and manuscript review.

\section{REFERENCES}

ABOURACHED, C.; ENGLISH, M.J.; LIU, H. Wastewater treatment by microbial fuel cell (MFC) prior irrigation water reuse. Journal of Cleaner Production, v.137, p.144-149, 2016. DOI: https://doi.org/10.1016/j. jclepro.2016.07.048

AHN, J.H.; JEONG, W.S.; CHOI, M.Y.; KIM, B.Y.; SONG, J.; WEON, H.Y. Phylogenetic diversity of dominant bacterial and archaeal communities in plant-microbial fuel cells using rice plants. Journal of Microbiology Biotechnology, v.24, p.1707-1718, 2014. DOI: https://doi. org/10.4014/jmb.1408.08053

ALSHARIF, M.H.; KIM, J.; KIM, J.H. Energy optimization strategies for eco-friendly cellular base stations. Energies, v.11, n.6, p.1500, 2018. DOI: https://doi.org/10.3390/ en 11061500

BLOSSFELD, S.; SUESSMILCH, S.; LE MARIÉ, C.A.; KUHN, A.J. Exploration of key rhizosphere parameters in Plant MFCs. Communications in Agricultural and Applied Biological Sciences, v.76, p.7-9, 2011.
BOMBELLI, P.; IYER, D.M.R.; COVSHOFF, S.; MCCORMICK, A.J.; YUNUS, K.; HIBBERD, J.M.; FISHER, A.C.; HOWE, C.J. Comparison of power output by rice (Oryza sativa) and an associated weed (Echinochloa glabrescens) in vascular plant bio-photovoltaic (VP-BPV) systems. Applied Microbiology Biotechnology, v.97, p.429-438, 2013. DOI: https://doi.org/ 10.1007/s00253012-4473-6

BRUNELLI, D.; TOSATO, P.; ROSSI, M. Flora health wireless monitoring with plant-microbial fuel cell. Procedia Engineering, v.168, p.1646-1650, 2016. DOI: https://doi.org/10.1016/j.proeng.2016.11.481

CHICAS, S.D.; SIVASANKAR, V.; OMINE, K.; VALLADAREZ, J.; MYLSAMY, P. Plant microbial fuel cell technology: developments and limitations. In: Microbial Fuel Cell Technology for Bioelectricity. Cham: Springer, 2018. p.49-65.

DENG, H.; CHEN, Z.; ZHAO, F. Energy from plants and microorganisms: progress in Plant-Microbial Fuel Cells. Chemistry \& Sustainability, Energy \& Material, v.5, p.1006-1011, 2012. DOI: https://doi.org/10.1002/ cssc. 201100257

ELSHOBARY, M.E.; ZABED, H.M.; YUN, J.; ZHANG, G.; QI, X. Recent insights into microalgae-assisted microbial fuel cells for generating sustainable bioelectricity. International Journal of Hydrogen Energy, v.46, n.4, p.3135-3159, 2020. DOI: https://doi.org/10.1016/j. ijhydene.2020.06.251

ERICKSON, L.E.; JENNINGS, M. Energy, transportation, air quality, climate change, health nexus: Sustainable energy is good for our health. AIMS Public Health, v.4, n.1, p.47-61, 2017. DOI: https://doi.org/10.3934/ publichealth.2017.1.47

FU, C.C.; SU, C.H.; HUNG, T.C.; HSIEH, C.H.; SURYANI, D.; WU, W. Effects of biomass weight and light intensity on the performance of photosynthetic microbial fuel cells with Spirulina platensis. Bioresource Technology, v.100, p.4183-4186, 2009. DOI: https://doi.org/10.1016/j. biortech.2009.03.059

FU, C.C.; HUNG, T.C.; WU, W.T.; WEN, T.C.; SU, C.H. Current and voltage responses in instant photosynthetic microbial cells with Spirulina platensis. Biochemical Engineering Journal, v.52, p.175-180, 2010. DOI: https:// doi.org/10.1016/j.bej.2010.08.004 
GUO, S.; LIU, Q.; SUN, J.; JIN, H. A review on the utilization of hybrid renewable energy. Renewable and Sustainable Energy Reviews, v.91, p.1121-1147, 2018. DOI: https://doi.org/10.1016/j.rser.2018.04.105

HELDER, M.; STRIK, D.P.; TIMMERS, R.A.; RAES, S.M.; HAMELERS, H.V.; BUISMAN, C.J. Resilience of roof-top plant-microbial fuel cells during Dutch winter. Biomass \& Bioenergy, v.51, p.1-7, 2013. DOI: https://doi. org/10.1016/j.biombioe.2012.10.011

HÖRMANN, V.; BRENSKE, K.R.; ULRICHS, C. Assessment of filtration efficiency and physiological responses of selected plant species to indoor air pollutants (toluene and 2-ethylhexanol) under chamber conditions. Environmental Science and Pollution Research, v.25, n.1, p.447-458, 2018. DOI: https://doi.org/10.1007/ s11356-017-0453-9

HUNG, Y.H.; LIU, T.Y.; CHEN, H.Y. Renewable coffee waste-derived porous carbons as anode materials for high-performance sustainable microbial fuel cells. ACS Sustainable Chemistry \& Engineering, v.7, n.20, p.16991-16999, 2019. DOI: https://doi.org/10.1021/ acssuschemeng.9b02405

IM, S.W.; LEE, H.J.; CHUNG, J.W.; AHN, Y.T. The effect of electrode spacing and size on the performance of soil microbial fuel cells (SMFC). Journal of Korean Society Environmental Engineers, v.36, p.758-763, 2014. DOI: https://doi.org/10.4491/KSEE.2014.36.11.758

KABUTEY, F.T.; ZHAO, Q.; WEI, L.; DING, J.; ANTWI, P.; QUASHIE, F.K.; WANG, W. An overview of plant microbial fuel cells (PMFCs): Configurations and applications. Renewable and Sustainable Energy Reviews, v.110, p.402-414, 2019. DOI: https://doi. org/10.1016/j.rser.2019.05.016

KWON, K.J.; PARK, B.J. Particulate matter removal of indoor plants, Dieffenbachia amoena ' Marianne' and Spathiphyllum spp. according to light intensity. Journal of the Korean Institute of Landscape Architecture, v.46, n.2, p.62-68, 2018. DOI: https://doi.org/10.9715/ KILA.2018.46.2.062

LEE, H.H.; HA, S.K.; KIM, K.H.; KANG, J.Y. Comparison of the European Standard methods and the Rural Development Administration methods for determining physical properties of horticultural substrates. Korean Journal of Soil Science and Fertilizer, v.39, n.2, p.116$122,2006$.

LIN, F.T.; KUO, Y.C.; HSIEH, J.C.; TSAI, H.Y.; LIAO, Y.T.; LEE, H.C. A self-powering wireless environmental monitoring system using soil energy. IEEE Sensors Journal, v.15, p.3751-3758, 2015. DOI: https://doi. org/10.1109/JSEN.2015.2398845
NITISORAVUT, R.; REGMI, R. Plant microbial fuel cells: a promising biosystems engineering. Renewable and Sustainable Energy Reviews, v.76, p.81-89, 2017. DOI: https://doi.org/10.1016/j.rser.2017.03.064

ROSA, E.O.L.; CASTILLO, J.V.; CAMPOS, M.C.; POOL, G.R.B.; NUÑEZ, G.B.; ATOCHE, A.C.; AGUILAR, J.O. Plant microbial fuel cells-based energy harvester system for self-powered IoT applications. Sensors, v.19, n.6, p.1378, 2019. DOI: https://doi.org/10.3390/s19061378

PAREDES, M.; QUILES, M.J. Chilling stress and hydrogen peroxide accumulation in Chrysanthemum morifolium and Spathiphyllum lanceifolium. Involvement of chlororespiration. Journal of plant physiology, v.211, p.36-41, 2017. DOI: https://doi.org/10.1016/j. jplph.2016.11.015

PARSEH,I.;TEIRI,H.;HAJIZADEH,Y.;EBRAHIMPOUR, $\mathrm{K}$. Phytoremediation of benzene vapors from indoor air by Schefflera arboricola and Spathiphyllum wallisii plants. Atmospheric Pollution Research, v.9, n.6, p.1083-1087, 2018. DOI: https://doi.org/10.1016/j.apr.2018.04.005

REGMI,R.;NITISORAVUT,R.; CHAROENROONGTAVEE, S.; YIMKHAOPHONG, W.; PHANTHURAT, O. Earthen potplant microbial fuel cell powered by Vetiver for bioelectricity production and wastewater treatment. Clean Soil Air Water, v.46, n.3, p.1700193, 2018. DOI: https://doi.org/10.1002/ clen.201700193

SARMA, P.J.; MOHANTY, K. Epipremnum aureum and Dracaena braunii as indoor plants for enhanced bio-electricity generation in a plant microbial fuel cell with electrochemically modified carbon fiber brush anode. Journal of Bioscience and Bioengineering, v.126, p.404-410, 2018. DOI: https://doi.org/10.1016/j. jbiosc.2018.03.009

SATHISH-KUMAR, K.; VIGNESH, V.; CABALLEROBRIONES, F. Sustainable power production from plant-mediated microbial fuel cells. In: Sustainable Agriculture towards Food Security. Singapore: Springer, 2017. p.85-107.

SHUBA, E.S.; KIFLE, D. Microalgae to biofuels:'Promising'alternative and renewable energy, review. Renewable and Sustainable Energy Reviews, v.81, p.743-755, 2018. DOI: https://doi.org/10.1016/j. rser.2017.08.042

SOPHIA, A.C.; SREEJA, S. Green energy generation from plant microbial fuel cells (PMFC) using compost and a novel clay separator. Sustainable Energy Technologies and Assessments, v.21, p.59-66, 2017. DOI: https://doi. org/10.1016/j.seta.2017.05.001 
SUDIRJO, E.; DE JAGER, P.; BUISMAN, C.J.; STRIK, D.P. Performance and long distance data acquisition via LoRa technology of a tubular plant microbial fuel cell located in a paddy field in West Kalimantan, Indonesia. Sensors, v.19, n.21, p.4647, 2019. DOI: https://doi. org/10.3390/s19214647

TOMMASI, T.; LOMBARDELLI, G. Energy sustainability of Microbial Fuel Cell (MFC): A case study. Journal of Power Sources, v.356, p.438-447, 2017. DOI: https://doi. org/10.1016/j.jpowsour.2017.03.122

XU, L.; ZHAO, Y.; DOHERTY, L.; HU, Y.; HAO, X. The integrated processes for wastewater treatment based on the principle of microbial fuel cells: a review. Critical Reviews in Environmental Science and Technology, v.46, n.1, p.60-91, 2016. DOI: https://doi.org/10.1080/106 43389.2015.1061884
XU, X.; WEI, Z.; JI, Q.; WANG, C.; GAO, G. Global renewable energy development: Influencing factors, trend predictions and countermeasures. Resources Policy, v.63, p.101470, 2019. DOI: https://doi.org/10.1016/j. resourpol.2019.101470

ZHANG, B.; WANG, B.; WANG, Z. Role of renewable energy and non-renewable energy consumption on EKC: evidence from Pakistan. Journal of Cleaner Production, v.156, p.855-864, 2017. DOI: https://doi.org/10.1016/j. jclepro.2017.03.203 